Editorial

\title{
Wind energy modeling and its application to the transportation system
}

\section{Editorial}

The most exciting ongoing tensions in an academic multimedia journal is the question of where to publish new finding and/or prediction in an appropriate media to let it know to the global scientific community. The journal of MOJ Civil Engineering could be the solution for it since it publishes peer reviewed civil and environmental engineering science research on the basis of innovativeness in terms of sustainability thinking, modeling, finding, and its possible application to protect the earth. Subsequently, the journal shall reach out all researchers, scientists, technology developers, and policy makers, and to assist to efforts implementation of Civil Engineering science in daily lives for the benefit of mankind. On behalf of this journal MOJ Civil Engineering, I welcome all scholars in civil engineering round the world to submit their research paper for rapid publication which will provide a forum for reporting innovative research findings that can be implemented to support building a better world.
Volume I Issue I - 2016

Faruque Hossain

Environmental Planning Scientist, Columbia University, USA

Correspondence: Faruque Hossain, Environmental Planning Scientist, Columbia University, USA, Tel 347-833-9905, Emailfaruque55@aol.com

Received: August 1I, 2016 | Published: August 19, 2016

\section{Acknowledgements}

None.

\section{Conflict of interest}

The author declares no conflict of interest. 